\title{
Phytoprotection
}

\section{Effects of soil compaction, temperature, and moisture on the development of the Fusarium root rot complex of pea in southwestern Ontario}

\author{
J.C. Tu
}

Volume 75, numéro 3, 1994

URI : https://id.erudit.org/iderudit/706059ar

DOI : https://doi.org/10.7202/706059ar

Aller au sommaire du numéro

Éditeur(s)

Société de protection des plantes du Québec (SPPQ)l

ISSN

0031-9511 (imprimé)

1710-1603 (numérique)

Découvrir la revue

Citer cet article

Tu, J. (1994). Effects of soil compaction, temperature, and moisture on the development of the Fusarium root rot complex of pea in southwestern Ontario. Phytoprotection, 75(3), 125-131. https://doi.org/10.7202/706059ar
Résumé de l'article

Le pourridié fusarien du pois (Fusarium spp.) constitue un complexe affecté par la compaction, la température et l'humidité du sol. L'effet de ces facteurs sur la gravité des pourritures fusariennes et sur la croissance du pois (Pisum sativum) a été étudié en environnement contrôlé. Le sol utilisé, issu d'un champ ayant des antécédents connus de la maladie, était infesté par les agents pathogènes qui causent le pourridié fusarien. Plusieurs niveaux de chaque facteur ont été utilisés. En environnement contrôlé, les résultats ont montré qu'un accroissement de la densité apparente du sol dû à la compaction augmentait significativement l'incidence et l'intensité du pourridié fusarien et réduisait de façon appréciable le poids frais des plantes de pois. L'augmentation graduelle de la température du sol de 10 à $30^{\circ} \mathrm{C}$ a résulté en un accroissement de l'intensité des pourritures racinaires et de l'expression des symptômes foliaires. À un niveau d'humidité du sol équivalant à $70 \%$ de la capacité au champ, les plantes de pois avaient une intensité de pourridié fusarien plus faible que celles cultivées dans un sol à 100, 50 ou $25 \%$ de la capacité au champ. Les plantes de pois soumises à des inondations temporaires ont présenté une incidence et une intensité de pourritures racinaires accrues lorsque la durée de l'inondation est passée de 1 à 5 jours.
Ce document est protégé par la loi sur le droit d'auteur. L'utilisation des services d'Érudit (y compris la reproduction) est assujettie à sa politique d'utilisation que vous pouvez consulter en ligne.

https://apropos.erudit.org/fr/usagers/politique-dutilisation/ 


\title{
Effects of soil compaction, temperature, and moisture on the development of the Fusarium root rot complex of pea in southwestern Ontario
}

\author{
Jui Chang $\mathrm{Tu}^{1}$
}

Received 1994-04-14; accepted 1994-11-23

The pea root rot complex (Fusarium spp.) is known to be affected by compaction, temperature, and moisture of the soils. This paper reports the effects of these factors on root rot severity and pea (Pisum sativum) growth tested in a controlled environment, using a Fusarium-infested soil collected from a field with a severe root rot history. For each factor, several increments were used. The results showed that in a controlled environment, an increase in soil bulk density due to compaction significantly increased root rot incidence and disease severity, and drastically reduced the fresh weight of pea plants. Stepwise increases in soil temperature from 10 to $30^{\circ} \mathrm{C}$ resulted in increases in estimated root rot severity and foliar symptom expression. Pea plants grown in soil moisture at $75 \%$ of field capacity had significantly lower Fusarium root rot incidence and severity than those grown in soil at $100 \%, 50 \%$ or $25 \%$ of field capacity. Pea plants subjected to temporary flooding exhibited an increased root rot incidence and severity as the duration of flooding increased from 1 to $5 \mathrm{~d}$.

Tu, J.C. 1994. Effet de la compaction, de la température et de l'humidité du sol sur le développement du complexe du pourridié fusarien du pois dans le sud-ouest de l'Ontario. PHYTOPROTECTION 75: 125-131.

Le pourridié fusarien du pois (Fusarium spp.) constitue un complexe affecté par la compaction, la température et l'humidité du sol. L'effet de ces facteurs sur la gravité des pourritures fusariennes et sur la croissance du pois (Pisum sativum) a été étudié en environnement contrôlé. Le sol utilisé, issu d'un champ ayant des antécédents connus de la maladie, était infesté par les agents pathogènes qui causent le pourridié fusarien. Plusieurs niveaux de chaque facteur ont été utilisés. En environnement contrôlé, les résultats ont montré qu'un accroissement de la densité apparente du sol dû à la compaction augmentait significativement l'incidence et l'intensité du pourridié fusarien et réduisait de façon appréciable le poids frais des plantes de pois. L'augmentation graduelle de la température du sol de 10 à $30^{\circ} \mathrm{C}$ a résulté en un accroissement de l'intensité des pourritures racinaires et de l'expression des symptômes foliaires. À un niveau d'humidité du sol équivalant à $70 \%$ de la capacité au champ, les plantes de pois avaient une intensité de pourridié fusarien plus faible que celles cultivées dans un sol à 100,50 ou $25 \%$ de la capacité au champ. Les plantes de pois soumises à des inondations temporaires ont présenté une incidence et une intensité de pourritures racinaires accrues lorsque la durée de l'inondation est passée de 1 à 5 jours.

1. Research Station, Agriculture and Agri-Food Canada, Harrow, Ontario, Canada NOR 1G0 


\section{INTRODUCTION}

The severity of pea root rots in southwestern Ontario has been documented and their etiology resolved (Tu 1987). Fusarium solani (Mart.) Sacc. f. sp. pisi (F.R. Jones) W.C. Snyder \& H.N. Hans. and $F$. oxysporum Schlechtend.: Fr. f. sp. pisi (J.C. Hall) W.C. Snyder \& H.N. Hans. were found to be the principal causal agents of the root rot complex in this region. Losses attributed to these fungi in Ontario pea (Pisum sativum L.) production amount to millions of dollars annually (Tu 1987). Incidence and severity of these diseases were closely related to the inoculum concentration in the field and to cultivar susceptibility, but they also varied with location in the field, time and amount of rainfall, and temperature. Peas planted in late April in fields infested with the Fusarium pathogens would often grow normally until late June but then the foliage turned yellow and root rot became severe. The foliar symptoms often developed after periods of heavy rainfall and warm temperatures, and invariably appeared first in low areas of the field where temporary flooding occurred. Patches of foliar symptoms increased in size and coalesced to give a general yellow appearance to the crops. At this time, plants in lower areas of the fields began to wilt and die. Severe yellowing, wilting, and death of plants occurred in as little as 7-10 d. The initial variation in disease incidence and severity, and subsequent disease spread were associated chiefly with compaction, temperature and moisture of the soil.

The majority of soils in southwestern Ontario are clays or clay loams. In Essex and Kent counties, where approximately $60 \%$ of peas are grown, more than $90 \%$ of the soil is Brookston clay, a fine textured soil classed as an orthic humic Gleysol which is susceptible to soil compaction. Soil compaction by farm equipment increases pea root rot incidence and severity (Burke et al. 1970; Vigier and Raghavan 1980). Tu (1987) observed that plants grew taller and had significantly lower root rot incidence and severity in raised seedbeds than in conventional flat seedbeds. Better plant growth and reduced incidence of root rots were correlated with lower soil penetrometer readings.

It was also observed that pea plants grown in flat seedbeds were often subjected to temporary localized flooding after a heavy rainfall, most frequently in the lower areas of a field and in areas depressed by tractors or heavy equipment. Compacted soil not only drained more slowly but also had less moisture holding capacity than non-compacted soil, and thus was more flood prone. Plants grown in flooded areas were usually stunted and had a higher incidence and severity of root rots (Tu 1987). Temporary flooding is known to induce the production of substances toxic to plants (Patrick et al. 1964), reduce the aeration of root systems (Kramer 1983) and predispose plants to diseases (Yarwood 1959).

Soil compaction, soil moisture, and temperature vary continuously in the field and their effects on pea root rots are difficult to measure. Studies were therefore conducted in controlled environments to determine the effects of each of these factors on pea root rot. Once the impact of each factor is understood, improved cultural practices can be developed to alleviate pea root rot.

\section{MATERIALS AND METHODS}

A series of experiments was designed to investigate the effects of soil compaction, temperature and moisture on the incidence and severity of Fusarium wilt and root rot. All experiments were conducted under controlled conditions in growth chambers, and arranged in a randomized complete block design. Unless otherwise mentioned, naturally infested soil from a field heavily infested with $F$. oxysporum and $F$. solani was used (Tu 1987). All experiments were conducted using $20-\mathrm{cm}$ plastic pots with a susceptible pea (cv. Green Giant 512) and soil that contained $5 \times 10^{3}$ propagules of Fusarium (Tu, unpublished data) in which F. solani f. sp. pisi and F. oxysporum f. sp. pisi were distributed in a 7:4 ratio (Tu 1987). For each 
treatment, 5 pots were used with 10 plants pot $^{-1}$. Soil moisture was maintained at field capacity by placing the potted soil in a shallow tray of water to facilitate continued uptake of water from the bottom of the pot. Thus, the soil in the pots had adequate water without flooding or reducing gas exchange. The growth chambers were programmed for a 14-h photoperiod. The light source was a bank of cool-white fluorescent and incandescent lamps that provided an intensity of $280 \mu \mathrm{mol} \mathrm{m} \mathrm{m}^{-2} \mathrm{~s}^{-1}$ at the plant level. The temperature was adjusted to $22 \pm 1^{\circ} \mathrm{C}$ unless otherwise noted.

Root rot was estimated in two ways: incidence (percentage of plants infected) and severity (percent root area diseased). Disease severity in each plant was rated on a $0-9$ scale $0=$ no symptoms, $1=1-10 \%$ of root area diseased, $2=11-20, \ldots 9=81-100 \%$ diseased) by visual scoring of roots after washing the soil off the roots on a screen with running water. The same scale was used for the rating of foliar symptoms.

\section{Soil compaction}

Steamed and non-steamed infested soil at each of three bulk densities (1.2, 1.4 and $1.6 \mathrm{~g} \mathrm{~cm}^{-3}$ ) were used. Soil compaction was achieved by weighing the amount of soil needed for the volume of the pot and compressing the soil into the pot. Ten replicate pots for each level of compaction were planted with peas, maintained in a growth chamber for $6 \mathrm{wk}$ with the soil moisture maintained at field capacity, and assessed for incidence and severity of root rot, and for fresh weight.

\section{Temperature}

Pathogen-infested soil was used to fill a total of 35 pots. Peas were sown in every pot and kept in a growth chamber for $10 \mathrm{~d}$ to allow completion of germination. Then the 35 pots were divided into 5 groups ( 7 replicate pots group ${ }^{-1}$ ) which were incubated in growth chambers with temperatures adjusted to $10,15,20,25$, and $30^{\circ} \mathrm{C}$, respectively. Disease incidence and severity, and fresh weight of the plants, were rated 5 wk later. In a repetition of the study, temperatures assigned to growth chambers were re-randomized.

\section{Moisture}

The effect of soil moisture on Fusarium wilt and root rot was studied under conditions of flooding and of water stress associated with water deficits.

\section{Flooding}

Pathogen-infested soil was used to fill a total of 60 pots. The experiment was a randomized complete block design with 10 replications. The six treatments consisted of flooding for 0 (unflooded control), 1, 2, 3, 4, and 5 d. All pots were planted with peas ( 10 plants pot $\left.^{-1}\right)$ and were kept in a growth chamber at $22 \pm$ $1^{\circ} \mathrm{C}$ for 2 wk until the seedlings were about $8-10 \mathrm{~cm}$ in height. Each pot from the flooded group was put into a clean plastic bag. The opened end of the bag was left untied. Each bagged pot was placed into another $20-\mathrm{cm}$ pot so that the plastic bag was sandwiched between the two pots. The soil was flooded so that about $3 \mathrm{~cm}$ of the hypocotyls of the seedlings were submerged in water. Ten pots were removed from the plastic bags each day for $5 \mathrm{~d}$ and allowed to drain. The pots were kept in a growth chamber at $22 \pm 1{ }^{\circ} \mathrm{C}$ and disease ratings were made $6 \mathrm{wk}$ later. The experiment was repeated once.

\section{Water stress}

Pathogen-infested soil was used to fill a total of 40 pots. After sowing, 10 of the pots were watered routinely to maintain the soil moisture at field capacity. The rest of the pots were divided into three groups and were maintained at 75,50 and $25 \%$ field capacity ( $\pm 10 \%$ ) in a greenhouse at $21 \pm 2^{\circ} \mathrm{C}$. Disease ratings and fresh weight of plants were taken 6 wk after sowing.

\section{Statistical analysis}

Statistical computations were performed using SAS software (SAS Institute Inc. 1990 ). Observations of repeated experiments were subjected to analyses of homogeneity of variance and pooled accordingly. Fisher's protected least significant difference test was used for mean comparison in soil compaction experiment. In other experiments, regression analyses (regression models) 
were used to examine quantitative relationships between dependent and response variables. In the temperature experiment, plant height increased with increase in temperature from 10 to $25^{\circ} \mathrm{C}$ and then sharply decreased as temperature reached $30^{\circ} \mathrm{C}$. Therefore two regression models were derived for plant height.

\section{RESULTS AND DISCUSSION}

\section{Effect of soil compaction on root rots}

An increase in soil compaction from 1.2 to $1.6 \mathrm{~g} \mathrm{~cm}^{-3}$ progressively increased root rot incidence and severity, but not the percent incidence of infected plants (Table 1). Fresh weights of plants were also markedly reduced as soil compaction increased. The results are similar to those found in beans grown in compacted soil of reduced porosity and consequently of reduced water availability and aeration needed for normal plant growth, which not only predisposed plants to root rot, but reduced nodulation, nitrogen fixation and the rate of photosynthesis ( $\mathrm{Tu}$ and Buttery 1988; Tu and Tan 1988). All of these adverse influences may contribute to the decrease in fresh weight of plants.

\section{Effect of soil temperature on root rots}

The number of lesions plant ${ }^{-1}$ increased with temperature up to $25^{\circ} \mathrm{C}$ (Table 2). The number of lesions at $30^{\circ} \mathrm{C}$ was numerically but non-significantly lower than at $25^{\circ} \mathrm{C}$, indicating that disease incidence probably peaked between
25 and $30^{\circ} \mathrm{C}$. However, root rot severity increased progressively with soil temperature between 10 and $30^{\circ} \mathrm{C}$. The largest increase was between 25 and $30^{\circ} \mathrm{C}$. The foliar symptoms also increased with increasing temperature. The foliar symptoms increased slightly between 20 and $25^{\circ} \mathrm{C}$ and then drastically between 25 and $30^{\circ} \mathrm{C}$. At $30^{\circ} \mathrm{C}$, the diseased plants were severely stunted and about $80 \%$ of the foliage was yellow.

High temperature correlated with disease severity and foliar symptoms (Table 2). Tu (1987) showed that soil associated with the Ontario root rot complex contained $F$. solani and $F$. oxysporum in a ratio of approximately 7:4 which generated a disease severity of 3.2 and 8.4 , respectively. Therefore, the disease severity and symptom expression in the present study reflected predominately those of $F$. oxysporum as opposed to $F$. solani. This explanation is in general agreement with those obtained for Fusarium wilt in several other works (Gardiner et al. 1987; Hood and Stewart 1957; Tims 1962; Walker 1941). High temperatures ( 30 and $35^{\circ} \mathrm{C}$ ) enhanced symptom development of cabbage yellows, watermelon and chrysanthemum wilt of Fusarium. The optimum temperature for symptom expression in vivo was higher than that for in vitro growth. In the case of Fusarium root rot of pea and bean, the optimal temperature for disease development was reported to be $21^{\circ} \mathrm{C}$ (Alberghina et al. 1979; Miller and Burke 1985; Sippell and Hall 1982).

Fresh weight was highest at $20^{\circ} \mathrm{C}$. Apparently, this temperature is most

Table 1. Effect of soil compaction on incidence and severity of root rot and on fresh weight of pea plants

\begin{tabular}{|c|c|c|c|c|c|}
\hline $\begin{array}{l}\text { Degree of } \\
\text { compaction }\end{array}$ & $\begin{array}{c}\text { Soil bulk } \\
\text { density } \\
\left(\mathrm{g} \mathrm{cm}^{-3}\right)\end{array}$ & $\begin{array}{c}\text { Diseased } \\
\text { plants } \\
(\%)\end{array}$ & $\begin{array}{c}\text { Lesions } \\
\text { (number plant }{ }^{-1} \text { ) }\end{array}$ & $\begin{array}{c}\text { Root rot } \\
\text { severity } \\
(0-9)\end{array}$ & $\begin{array}{c}\text { Fresh } \\
\text { weight } \\
\left(\text { g plant }^{-1}\right)\end{array}$ \\
\hline None ${ }^{\S}$ & 1.2 & $67.5 b^{\ddagger}$ & $2.4 \mathrm{a}$ & $3.2 \mathrm{a}$ & $2.94 \mathrm{c}$ \\
\hline Moderate & 1.4 & $65.0 \mathrm{a}$ & $2.8 \mathrm{~b}$ & $4.2 \mathrm{~b}$ & $2.38 \mathrm{~b}$ \\
\hline Heavy & 1.6 & $68.1 \mathrm{~b}$ & $3.6 \mathrm{c}$ & $4.8 \mathrm{c}$ & $1.82 \mathrm{a}$ \\
\hline
\end{tabular}

$\S$ Control treatment.

₹ Means within a column followed by the same letter are not significantly different $(P \leq 0.05)$, according to the Fisher's protected least significant difference test. 
Table 2. Effect of temperature on root rot severity, foliar symptoms and plant growth in pea, and statistics for the regression model

\begin{tabular}{cccccc}
\hline $\begin{array}{c}\text { Temperature } \\
\left({ }^{\circ} \mathrm{C}\right)\end{array}$ & $\begin{array}{c}\text { Lesions } \\
\text { (number plant }{ }^{-1} \text { ) }\end{array}$ & $\begin{array}{c}\text { Root rot } \\
\text { severity } \\
(0-9)\end{array}$ & $\begin{array}{c}\text { Foliar } \\
\text { symptoms } \\
(0-9)\end{array}$ & $\begin{array}{c}\text { Fresh weight } \\
\text { (g plant }{ }^{-1} \text { ) }\end{array}$ & $\begin{array}{c}\text { Plant } \\
\text { height } \\
(\mathrm{cm})\end{array}$ \\
\hline 10 & 0.5 & 0.8 & 0 & 2.73 & 17.4 \\
15 & 1.1 & 1.3 & 1.8 & 2.17 & 22.7 \\
20 & 1.7 & 3.2 & 1.9 & 3.35 & 23.9 \\
25 & 2.6 & 4.5 & 3.5 & 2.02 & 27.1 \\
30 & 2.3 & 8.2 & 8.9 & 0.19 & 8.5
\end{tabular}

Regression analysis ${ }^{\S}$

Equation $(Y=) \quad-0.40+0.10 T^{\ddagger} \quad-3.60+0.36 \mathrm{~T} \quad-4.58+0.39 \mathrm{~T}$

\begin{tabular}{lllllcc}
$R^{2}$ & & & & $\left(10 \leq \mathrm{T} \leq 25^{\circ} \mathrm{C}\right)$ & $\left(\mathrm{T}>25^{\circ} \mathrm{C}\right)$ \\
$R_{a}^{2}$ & 0.88 & 0.92 & 0.82 & 0.49 & 0.94 & 0.75 \\
$\sqrt{\mathrm{MSE}}$ & 0.84 & 0.89 & 0.76 & 0.32 & 0.91 & 0.70 \\
$P$ & 0.34 & 0.98 & 1.68 & 0.98 & 1.22 & 1.28 \\
\hline & 0.05 & 0.05 & 0.05 & 0.19 & 0.05 & 0.05 \\
\hline
\end{tabular}

$\S R^{2}$ : coefficient of determination; $R_{a}^{2}$ : coefficient of determination adjusted to degrees of freedom; $\sqrt{\mathrm{MSE}}$ : mean square error; $P$ : significance level based on simple regression analysis.

‡ T: temperature $\left({ }^{\circ} \mathrm{C}\right)$.

favorable to plant growth which compensated for damage associated with root rot. Fresh weight and plant height were greatly reduced when soil temperature was high. The observed values for root rot severity and foliar symptoms of 4.5 and 3.5 at $25^{\circ} \mathrm{C}$, respectively, and of 8.2 and 8.9 at $30^{\circ} \mathrm{C}$, respectively, indicated that foliar symptom was more favored by higher temperature than was root rot severity. At $30^{\circ} \mathrm{C}$, the majority of plants with root rot either died or were severely stunted.

\section{Effect of temporary flooding on root rots}

Root rot incidence and severity increased significantly when pea plants were grown in infested soil that was subjected to flooding for 1 to $5 \mathrm{~d}$ (Table 3). Disease progressively increased and fresh weight of the plants decreased with increased duration of flooding. The reduction in fresh weight may have resulted from a combination of increased root rot and other flooding effects. Similar effects caused by excessive moisture and temporary flooding have been documented previously in other pathogen-root rot combinations (Cook and Papendick 1972; Kuan and Erwin 1980; Miller et al. 1980; Shew 1983).

\section{Effect of soil moisture on root rots}

The lowest incidence and severity of infection and the greatest plant growth were observed at $75 \%$ of field capacity. Higher and lower levels of soil moisture resulted in higher percentages of infection and lower fresh weights. Soil moisture at $100 \%$ of field capacity resulted in the highest incidence of disease (Table 4). Plant growth when soil moisture was less than $75 \%$ of field capacity did not show an increase in disease incidence but lack of soil moisture (at $25 \%$ field capacity) greatly increased the severity of root rot. The results showed that either an excess or a deficiency of soil moisture could promote root rots.

Loosening the soil enhances plant growth and reduces root rot. Excessive soil moisture, such as temporary flooding, is detrimental to plant growth and also promotes root rot. High temperature increases disease severity of Fusarium wilt. From these facts, a combination of raised bed (e.g. $15 \mathrm{~cm}$ height) and early planting may help to avoid severe root rot and improve productivity of peas in Ontario. 
Table 3. Effect of temporary flooding on the incidence and severity of root rot and fresh weight of pea plants and statistics for the regression models

\begin{tabular}{|c|c|c|c|c|}
\hline $\begin{array}{l}\text { Duration } \\
\text { of flooding } \\
\text { (d) }\end{array}$ & $\begin{array}{l}\text { Diseased } \\
\text { plants } \\
(\%)\end{array}$ & $\begin{array}{l}\text { Lesions } \\
\text { (number plant }{ }^{-1} \text { ) }\end{array}$ & $\begin{array}{l}\text { Root rot } \\
\text { severity } \\
(0-9)\end{array}$ & $\begin{array}{l}\text { Fresh weight } \\
\left.\text { (g plant }{ }^{-1}\right)\end{array}$ \\
\hline 0 (control) & 67.5 & 2.4 & 3.2 & 2.94 \\
\hline 1 & 86.2 & 3.4 & 5.6 & 2.10 \\
\hline 2 & 91.6 & 4.9 & 6.9 & 1.98 \\
\hline 3 & 98.0 & 5.4 & 6.9 & 1.68 \\
\hline 4 & 98.0 & 6.3 & 7.4 & 1.48 \\
\hline 5 & 98.0 & 7.0 & 7.7 & 1.48 \\
\hline \multicolumn{5}{|c|}{ Regression analysis ${ }^{\S}$} \\
\hline Equation $(Y=)$ & $76.0+5.55 X^{\ddagger}$ & $2.60+0.92 X$ & $4.29+0.80 X$ & $2.62-0.27 X$ \\
\hline$R^{2}$ & 0.75 & 0.98 & 0.80 & 0.84 \\
\hline$R_{a}^{2}$ & 0.69 & 0.97 & 0.74 & 0.80 \\
\hline$\sqrt{\mathrm{MSE}}$ & 6.63 & 0.28 & 0.85 & 0.24 \\
\hline$P$ & 0.05 & 0.01 & 0.05 & 0.05 \\
\hline
\end{tabular}

Table 4. Effect of soil moisture on incidence and severity of root rot, and on fresh weight and height of pea plants

\begin{tabular}{cccccc}
\hline $\begin{array}{c}\text { Soil } \\
\text { moisture } \\
(\%)\end{array}$ & $\begin{array}{c}\text { Diseased } \\
\text { plants } \\
(\%)\end{array}$ & $\begin{array}{c}\text { Lesions } \\
\left.\text { (number plant }{ }^{-1}\right)\end{array}$ & $\begin{array}{c}\text { Root rot } \\
\text { severity } \\
(0-9)\end{array}$ & $\begin{array}{c}\text { Fresh weight } \\
\text { (g plant }{ }^{-1} \text { ) }\end{array}$ & $\begin{array}{c}\text { Plant height } \\
\text { (cm) }\end{array}$ \\
\hline $100^{5}$ & 83 & 3.3 & 3.9 & 2.87 & 29.7 \\
75 & 63 & 1.5 & 3.1 & 3.27 & 23.5 \\
50 & 72 & 1.5 & 3.9 & 2.39 & 20.2 \\
25 & 75 & 1.7 & 4.6 & 1.98 & 17.5 \\
$P^{\ddagger}$ & NS & NS & NS & 0.05 & 0.05 \\
\hline
\end{tabular}

Field capacity.

¥ P: significance level based on simple regression analysis; NS: non significant.

\section{REFERENCES}

Alberghina, A., A. Benni, and M.G. Fatino. 1979. Effects of temperature and polyphenols on fusaria, Fusarium oxysporum and Fusarium solani growth in peas. Phytopathol. Z. 96: 40-49.

Burke, D.W., D.J. Hagedorn, and J.E. Mitchell. 1970. Soil conditions and distributions of pathogens in relation to pea root rot in Wisconsin soils. Phytopathology 60: 403-406.
Cook, R.J., and R.I. Papendick. 1972. Influence of water potential of soils and plants on root disease. Annu. Rev. Phytopathol. 10: 349-374.

Gardiner, D.C., R.K. Horst, and P.E. Nelson. 1987. Symptom enhancement of Fusarium wilt of chrysanthemum by high temperatures. Plant Dis. 71: 1106-1109.

Hood, J.R., and R.N. Stewart. 1957. Factors affecting symptom expression in Fusarium wilt of Dianthus. Phytopathology 47: 173-178. 
Kramer, P.J. 1983. Water relations of plants. Acad. Press., New York. 489 pp.

Kuan, T.L., and D.C. Erwin. 1980. Predisposition effect of water saturation of soil on phytophthora root rot of alfalfa. Phytopathology 70: 981-986.

Miller, D.E., and D.W. Burke. 1985. Effects of low soil oxygen on fusarium root rot of beans with respect to seedling age and soil temperature. Plant Dis. 69: 328-330.

Miller, D.E., D.W. Burke, and T.M. Kraft. 1980. Predisposition of bean roots to attack by the pea pathogen, Fusarium solanif. sp. pisi, due to temporary oxygen stress. Phytopathology 70: 1221-1224.

Patrick, Z.A., T.A. Toussoun, and L.W. Koch. 1964. Effect of crop residue decomposition products on plant roots. Annu. Rev. Phytopathol. 2: 267-292.

SAS Institute Inc. 1990. SAS/STAT User's guide: version $6.0,4^{\text {th }} \mathrm{Ed}$. SAS Institute Inc. Cary, North Carolina. 943 pp.

Shew, H.D. 1983. Effects of soil matric potential on infection of tobacco by Phytophthora parasitica var. nicotianae. Phytopathology 73: 1160-1163.

Sippell, D.W., and R. Hall. 1982. Effects of pathogen species, inoculum concentration, temperature, and soil moisture on bean root rot and plant growth. Can. J. Plant Pathol. 4: 1-7.
Tims, E.C. 1962. The influence of soil temperature and soil moisture on the development of yellows in cabbage seedlings. J. Agric. Res. 33: 971-992.

Tu, J.C. 1987. Integrated control of the pea root rot disease complex in Ontario. Plant Dis. 71: 9-13.

Tu, J.C., and B.R. Buttery. 1988. Soil compaction reduces nodulation, nodule efficiency, and growth of soybean and white bean. Hortscience 23: 722-724.

Tu, J.C., and C.S. Tan. 1988. Soil compaction effect on photosynthesis, root rot severity, and growth of white beans. Can. J. Soil Sci. 68: 455-459.

Vigier, B., and G.S.V. Raghavan. 1980. Soil compaction effect in clay soils on common root rot in canning peas. Can. Plant Dis. Surv. 60: 43-45.

Walker, M.N. 1941. Fusarium wilt of watermelons. I. Effect of soil temperature on the wilt disease and the growth of watermelon seedlings. Fla. Agric. Exper. Stn. Bull. 363. 29 pp.

Yarwood, C.E. 1959. Predisposition. Pages 521-562 in J.G. Horsfall and A.E. Dimond (eds.), Plant pathology I. Acad. Press., New York. 